\author{
M.B. Turlubekova ${ }^{1, *}$, R.O.Bugubaeva ${ }^{2}$, R.S. Besspayeva ${ }^{3}$ \\ 1,2,Karaganda University of Kazpotrebsoyuz, Kazakhstan \\ ${ }^{3}$ Saken Seifullin Kazakh Agrotechnical University \\ 'bestielts@mail.ru,2prur@keu.ru,3brs_@mail.ru \\ ${ }^{1}$ https://orcid.org/0000-0002-7609-1450, ${ }^{2}$ https://orcid.org/0000-0002-3648-8365, ${ }^{3}$ https://orcid.org/0000-0002-3955-9237
}

\title{
Inclusive education in the republic of Kazakhstan and factors affecting its development
}

\section{Abstract}

Object: is the system of inclusive education in the context of state management policy.

The methods: The following methods were used in the study: theoretical, empirical methods, methods of highquality data processing, methods of mathematical and statistical processing: ranking, correlation.

An econometric model was constructed to test the hypothesis that there is a relationship between the growth rate of the number of children enrolled in inclusive education and the growth rate of the number of teachers in general education schools. tained.

The conclusions and results of the study were presented using a graphical method of presenting the results ob-

Findings: The author hypothesized that there is a relationship between the growth rate of the number of children enrolled in inclusive education and the growth rate of the number of teachers in general education schools. To prove or refute this hypothesis, the author conducted a regression analysis, which resulted in the conclusion that an increase in the number of teachers in general education schools is a significant and necessary condition for the further development of inclusive education.

Conclusions: Based on the regression analysis, the author of the article concluded that the increase in the number of teachers of general education schools contributes to an increase in the number of children enrolled in inclusive education.

The research analysis on the studied problem shows that at the present stage inclusion is the leading trend in the development of the education system. The quality of the development of inclusive education in Kazakhstan raises many questions for researchers, including the ineffectiveness of the use of innovative forms of education in inclusive education, the lack of knowledge of international experience, etc.

Keywords: inclusive education, education system, inclusion, management, preschool education, regulation, management system, innovative education.

\section{Introduction}

Inclusive education is currently an innovative process, which is based on an ideology that excludes any discrimination and ensures equal treatment of all people, while creating special conditions for children with special educational needs. This approach in education is recognized by the entire world community as the most humane, effective and socially significant and is one of the main in state and educational policy.

The idea of inclusive education today is actively developing in Kazakhstani society, but normative documents governing the process are not being adopted. The Education Act states that persons with special educational needs are children who experience permanent or temporary difficulties in obtaining education, which are due to their health condition. This led to the fact that inclusive education began to be interpreted as education for children with disabilities. Although these children are just one of the categories of children with special educational needs. Therefore, the implementation of inclusive education in the Republic of Kazakhstan raises for our state the question of the need to change public administration in the education system in the implementation of inclusive education in the context of globalization and digitalization of new learning technologies.

\section{Literature Review}

Many scientists are engaged in the problem of inclusive education. For example, Dyssegaard C.B., Larsen M.S. in their research they describe that as inclusive education develops, there is a gradual convergence of the systems of special and general education, united by common ideas in achieving success and sharing responsibility for its results (Dyssegaard et al.,55).

\footnotetext{
${ }^{*}$ Corresponding author.

E-mail address: bestielts@mail.ru
} 
Giangrego, M., Doyle M.B. argue that, in accordance with the strategic goals of the international educational process, the implementation of inclusive education presupposes a set of cardinal changes and modifications aimed at promoting anti-discrimination policies, creating an inclusive society and improving the quality of education for all children in line with the broad range of their educational needs (Giangreno et al., 63).

Safonova TV, Suntsova AS, Aslaeva RG consider the personality-oriented model of interaction with children as a structural component of professional readiness for inclusive education(Saphonova et al.,50), the purpose of which is to identify and analyze the features of the model interaction with learners from teachers of various types of educational organizations. ( Svenja et al.,569).

Timo S., and also Biktagirova G. F., Khitryuk V. V. They put forward their hypotheses about the need to rely on special (correctional) educational institutions as resource centers for supporting the practice of inclusion (Timo,560; Biktagirova et al.,185).

According to Hosford S., O'Sullivan SA, the teacher of an inclusive school should be ready for multifunctional activities, master the technologies of multi-level teaching, taking into account the individual and personal characteristics of students, at the same time teach children with different educational needs and opportunities (Hosford et al., 604) .

A significant problem, according to J. Sagner-Tapia, S. Schlessinger, is the restrictions applied by teachers to the inclusion of children with disabilities in general classes, since not all teachers are ready to encourage the participation of all without restrictions. The teachers themselves associate unpreparedness not so much with professional skills as with the attitude towards disability and the ability to learn determined by it (Sagner-Tapia et al.,.375; Schlessinger, 268).

The term "inclusive education" was brought to Kazakhstan by the National Scientific and Practical Center for Correctional Pedagogy (until 2004 it was called the "Republican Scientific and Practical Center for Social Adaptation, Vocational and Labor Rehabilitation of Children with Development Disabilities - RNTSP SATR") (Suleimenova, 2015).

In our opinion, inclusive education implies the individualization and differentiation of the environment and education in accordance with the needs of various children - gifted, with language problems, behavioral problems, etc.

\section{Results and discussions}

The author hypothesized that there is a relationship between the number of children enrolled in inclusive education and such factors as the number of qualified teachers in secondary schools and the use of Internet technologies. The use of Internet technologies for children with disabilities is of great importance and is part of the system of requirements for ensuring physical and informational accessibility of education for this category of schoolchildren and creating a barrier-free educational environment for them. Therefore, as a factor affecting the number of children covered by inclusive education, such an indicator as Internet technologies was taken.

To estimate the parameters of the two-factor regression equation, statistical data of the Statistics Committee of the Ministry of National Economy of the Republic of Kazakhstan for the period from 2010 to 2019 were used.

To prove or refute these hypotheses, the author conducted a regression analysis, as a result of which it was concluded that the use of Internet technologies, as well as the number of qualified teachers in general education schools is a significant and necessary condition for the further development of inclusive education, which is one of the most important tasks of the state policy of the Republic of Kazakhstan in the field of education.

The realization of the rights of children with disabilities to education is considered as one of the most important tasks of the state policy of the Republic of Kazakhstan in the field of education. Obtaining highquality education by children with disabilities is one of the basic and inalienable conditions for their successful socialization, ensuring their full participation in society, effective self-realization in various types of professional and social activities. The legislation of the Republic of Kazakhstan, in accordance with the fundamental international documents in the field of education, provides for the principle of equal rights to education for persons with disabilities.

The problem of inclusive education has a significant impact on the socio-economic development of the country. This is evidenced by data obtained in the course of studies by UNESCO, according to which the losses from disability of a part of the population in Europe and Central Asia amount to at least 35.6\% of global GDP. 
According to the World Health Organization (hereinafter - WHO), inclusive education is based on the right of all students to receive quality education that meets basic educational needs.

As defined by UNESCO, inclusive education refers to the process of meeting the diverse needs of all learners by increasing their participation in learning, cultural activities and community life, as well as reducing social exclusion within the education system and preventing exclusion from it.

The modern education system is focused primarily on students who meet certain requirements, who are able to study according to a common program for all. As a result, children with disabilities do not have the opportunity and conditions to participate in the general educational process. It is inclusive education that will help solve this problem.

Inclusion in education is reflected in the principles that make school education accessible to all children: ensuring physical access for students with disabilities to schools (transport, ramps, lifts); development of a mobile curriculum structure and a variety of educational methods to meet the needs of all students, including:

- the need for full-fledged and diverse personal formation and development - taking into account individual inclinations, interests, motives and abilities (personal success);

- the need for a person's organic entry into the social environment and fruitful participation in the life of society (social success);

- the need for the development of a person's universal labor and practical skills, readiness to choose a profession (professional success).

A number of factors have contributed to the emergence of an inclusive educational environment.

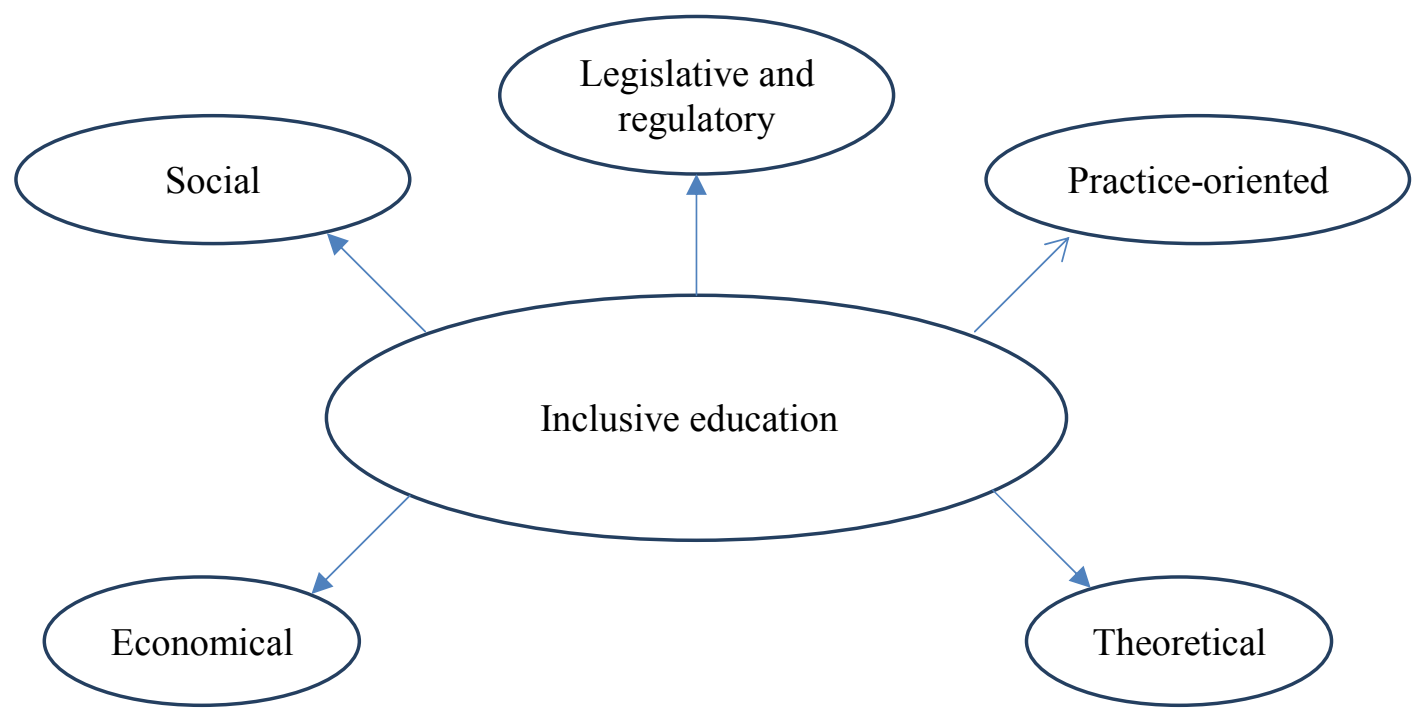

Figure 1. Factors contributing to the development of inclusive education

Note - Compiled by the authors

1. Social:

- society makes new demands on the availability and improvement of the quality of education;

- more and more children are born with disorders of the emotional sphere, intelligence, as well as autistic and other disorders that also need education;

- inclusion of parents in the educational process as a subject of learning.

2. Practice-oriented:

- inclusion of parents of "special" children in the educational process in the role of educators;

- the emergence of the position of "coordinator-methodologist" of inclusion;

- creation of professional communities, retraining courses for specialists in the field of supporting the inclusive educational process.

3. Economic:

- development of human resources.

4 Theoretical:

- the concept of continuing education;

- transition from a "medical" model of understanding disability to a "social" one. 
According to international and national legal acts, the policy of inclusive education is implemented through the following regulatory legal acts (Table 1) (Nogaibayev et al.,187).

Table 1. International and national legal acts regulating the issues of inclusive education

\begin{tabular}{|c|l|}
\hline Year & \multicolumn{1}{|c|}{ Regulatory legal acts regulating the issues of inclusive education } \\
\hline Internationallegalacts \\
\hline 1948 & Universal Declaration of Human Rights \\
\hline 1989 & UN Concept on the Rights of the Child \\
\hline 1990 & World Declaration on Education for All \\
\cline { 2 - 2 } & World Declaration on the Protection of the Living and Development of Children \\
\hline 1993 & Standard Rules on the Equalization of Opportunities for Persons with Disabilities \\
\hline 1994 & Salaman Declaration and Framework for Action on Education for Persons with Special Needs \\
\hline 2000 & Dakar Framework for Action, Education for All Movement \\
\hline 2006 & UN Concept on the Rights of Persons with Disabilities \\
\hline Nationallegalacts \\
\hline 1995 & Constitution of the Republic of Kazakhstan \\
\hline 2002 & Law on social medical and pedagogical correctional support for children with disabilities \\
\cline { 2 - 2 } & Law "On the Rights of the Child in the Republic of Kazakhstan" \\
\hline 2005 & Law "On social protection of disabled people in the Republic of Kazakhstan" \\
\hline 2007 & EducationAct" \\
\hline 2008 & Law "On Special Social Services" \\
\hline 2010 & State program for the development of education in the Republic of Kazakhstan for 2011-2020 \\
\hline 2015 & $\begin{array}{l}\text { On the approval of Conceptual approaches to the development of inclusive education in the Republic } \\
\text { of Kazakhstan }\end{array}$ \\
\hline 2016 & $\begin{array}{l}\text { State program for the development of education and science of the Republic of Kazakhstan for 2016- } \\
\text { 2019. }\end{array}$ \\
\hline 2017 & Standard rules for the activities of types of special educational organizations \\
\hline $\begin{array}{l}\text { Note - Compiled on the basis of the source: Framework for monitoring inclusive education in the Republic of Kazakhstan / G. } \\
\text { Nogaybaeva, S. Zhumazhanova, E. Korotkikh - Astana: IAC, 2017 - 28. }\end{array}$ \\
\hline
\end{tabular}

As a result of the study, it was revealed that inclusive education in the territory of the Republic of Kazakhstan (hereinafter referred to as the RK) is regulated by the Constitution of the Republic of Kazakhstan, the Law of the RK No. 319-III of July 27, 2007 "On Education", the State Program for the Development of Education in the Republic of Kazakhstan for 2011-2020 years ", approved by the Decree of the President of the Republic of Kazakhstan No. 1118 dated December 7, 2010 (National educational academy named after Altynsarin, 16, State program,2010).

The Law of the Republic of Kazakhstan "On Education" dated July 27, 2007 No. 319-III (with amendments and additions as of 07.07.2020) defines the term "special conditions for obtaining education" - "conditions including special educational programs and teaching methods, technical and other means, the environment of life, as well as medical, social and other services, without which it is impossible to master general educational and educational programs by persons with OOP "(Law of RK, 2007 ).

Schools that have created conditions for inclusive education emphasize the importance of comprehensive accounting of both the material and technical, educational, methodological and personnel conditions necessary for the children of the PLO.

The main difficulties in the implementation of inclusive education are associated with the material costs of creating conditions in a general education school for teaching children with OEP. Significant funds are required to provide the school with special teaching materials, technical auxiliary (compensatory) teaching aids, and adaptation of classrooms.

At the same time, the problems of inclusive education cannot be solved locally: it is impossible to create good conditions for children with OOP and not to create a rich and diverse educational environment for other children. The success of the implementation of inclusive education directly depends on the solution of general problems of the school education system, such as high class size, low teacher status, weak ICT equipment, inflexible curriculum and others.

For the quality implementation of inclusive approaches, cooperation with special educators is important. According to the opinion poll, the cooperation of teachers of mass and special educational organizations has not been effectively established in the country. 
Analysis of the factors influencing the quality of education of children with OEP, studying the opinions of all participants in the educational process allow us to conclude that the leading factor in the development of inclusive education is a high level of readiness of the teaching staff to work with such children.

In 2018, according to the NED, there are 45618 children with PLO in the republic aged 0 to 6 years, which is $1.9 \%$ of the total population of this age category. In special kindergartens, 5,016 children with OOP were brought up. Special groups of preschool organizations of general type were visited by 9444 children with OOP, mass groups (inclusively) - 5529 children with OOP (Figure 2) (Atanaev et al., 364).

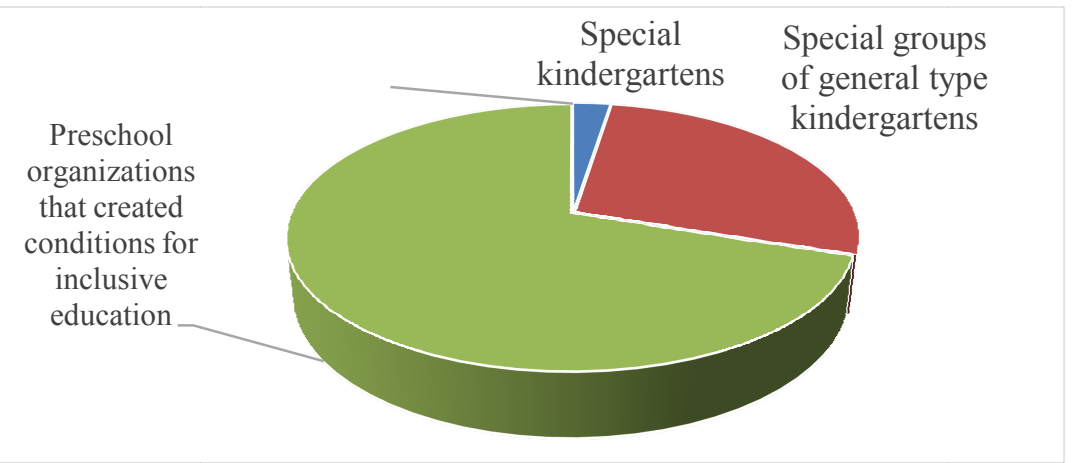

Figure 2. The network of preschool organizations for children with OOP for 2018, units

\section{Note-compiled by the authors}

Psychological, medical and pedagogical correctional support for children with OOP is provided in special-purpose kindergartens. The largest number of them operate in Almaty (Nogayboaeva et al.,187), Pavlodar (Hosford et al.,604-620), East Kazakhstan (Biktagirova et al., 185-194) regions. In seven regions: Akmola, Kostanay, Kyzylorda, Almaty, Zhambyl, West Kazakhstan and North Kazakhstan regions - there is no network of special Far East Military District. In these regions, a network of general kindergartens with special groups is developed. In total, there are 206 kindergartens in Kazakhstan, where special groups have been created to work with children with OOP (Table 2) (Atanaeva et al., 364).

Table 2. Network and contingent of children of special preschool educational organizations, units / person

\begin{tabular}{|c|c|c|c|c|c|c|}
\hline \multirow{2}{*}{ Region } & \multirow{2}{*}{$\begin{array}{c}\text { Preschool } \\
\text { organizations for } \\
\text { special purposes }\end{array}$} & \multicolumn{2}{|c|}{ Which are } & \multirow{2}{*}{$\begin{array}{l}\text { Preschool organizations } \\
\text { of general type with } \\
\text { special in groups }\end{array}$} & \multicolumn{2}{|c|}{ Whichare } \\
\hline & & groups & chidren & & groups & children \\
\hline Republic of Kazakstan & 44 & 325 & 5016 & 206 & 486 & 9444 \\
\hline Akmola region & 0 & 0 & 0 & 19 & 37 & 542 \\
\hline Aktube region & 4 & 39 & 600 & 10 & 22 & 334 \\
\hline Almaty region & 0 & 0 & 0 & 15 & 26 & 538 \\
\hline Atyrau region & 1 & 5 & 122 & 3 & 3 & 49 \\
\hline $\begin{array}{l}\text { WRK (Western region } \\
\text { of Kazakstan) }\end{array}$ & 0 & 0 & 0 & 12 & 22 & 257 \\
\hline Zhambyl region & 0 & 0 & 0 & 15 & 66 & 1822 \\
\hline Karagandy region & 1 & 9 & 135 & 23 & 94 & 2010 \\
\hline Kostanay region & 0 & 0 & 0 & 14 & 31 & 424 \\
\hline Kyzylorda region & 0 & 0 & 0 & 9 & 27 & 604 \\
\hline Mangystau region & 2 & 20 & 317 & 2 & 2 & 33 \\
\hline Pavlodar region & 7 & 45 & 679 & 4 & 7 & 106 \\
\hline $\begin{array}{l}\text { NRK (Northern region } \\
\text { of Kazakhstan) }\end{array}$ & 0 & 0 & 0 & 9 & 15 & 189 \\
\hline Turkestan region & 5 & 16 & 328 & 29 & 53 & 1380 \\
\hline $\begin{array}{l}\text { ERK (Eastern region } \\
\text { of Kazakhstan) }\end{array}$ & 6 & 46 & 724 & 13 & 25 & 429 \\
\hline Nur-Sultan city & 2 & 23 & 264 & 21 & 46 & 577 \\
\hline Almaty city & 11 & 78 & 1169 & 8 & 10 & 150 \\
\hline Shymkent city & 5 & 44 & 678 & 0 & 0 & 0 \\
\hline
\end{tabular}


In 2018, 20.1\% of pre-school organizations (1,232 units) created conditions for inclusive education, which is $10.1 \%$ higher than in 2016 . The highest percentage of preschool organizations that created conditions for children with OOP was registered in Almaty (200 units) and Zhambyl (106 units), Kyzylorda (119 units), Pavlodar (124 units), Turkestan (99 units), Karaganda (70 units) regions (Figure 3).

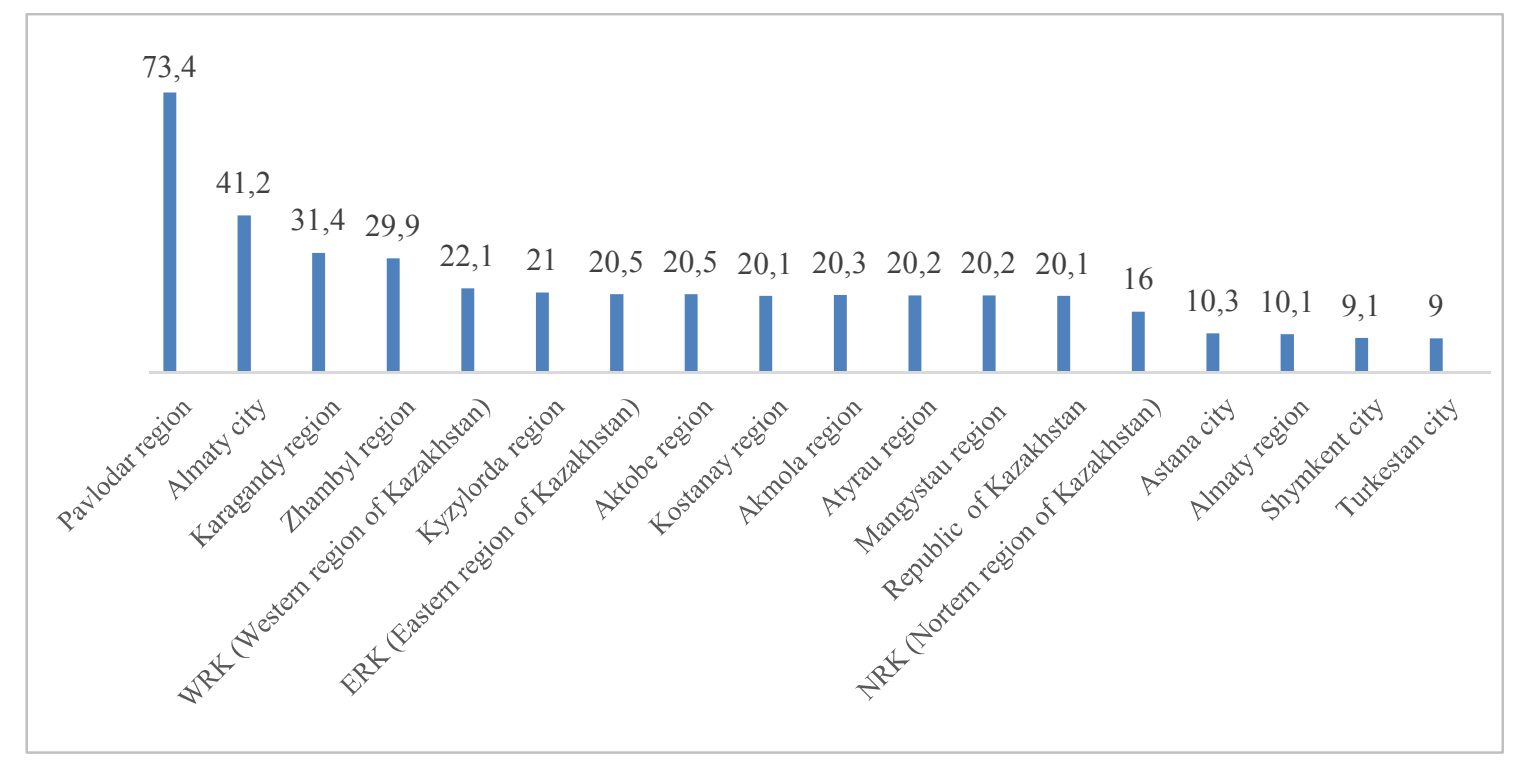

Figure 3. Dynamics of the network of preschool organizations that have created conditions for inclusive education and training in 2018, \%

Note-compiled by the authors

In these regions, local Executive bodies pay attention to the development of inclusion and allocate funds to provide educational organizations with special teaching materials, technical auxiliary (compensatory) training facilities, and adaptation of educational premises. If we consider inclusive education with the coverage of school children, then taking into account the regional aspect, the situation looks like this ((Figure 4) (www.kapital.kz).

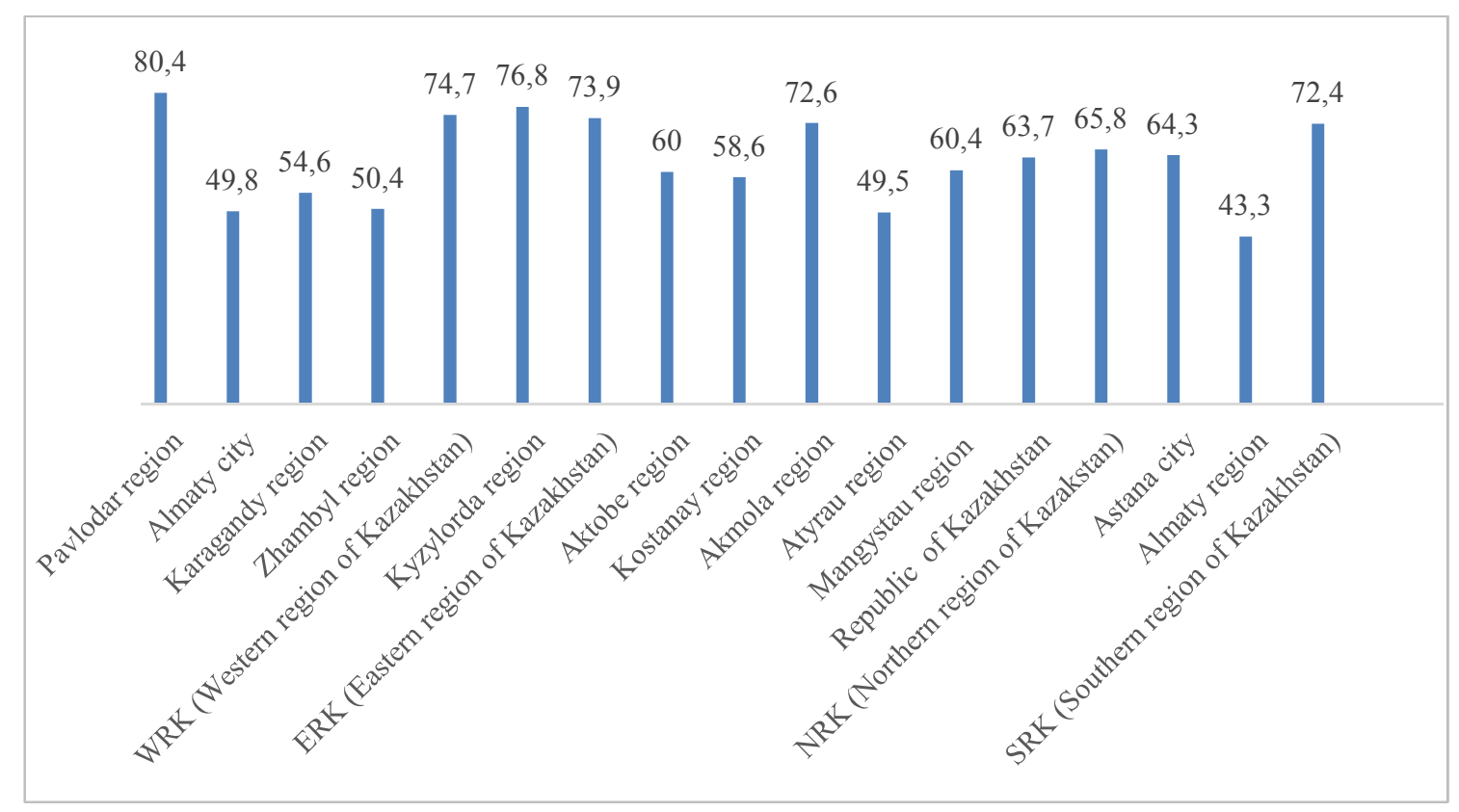

Figure 4. Percentage of schools that have created the conditions for inclusive education in the regional aspect of $2018, \%$

Note-compiled by the authors 
So, on the basis of secondary school No. 27 in Karaganda, which is a republican experimental platform of the Ministry of Education and Science of the Republic of Kazakhstan for the implementation of inclusive education, a sociological survey was conducted on the problem of joint education with children with disabilities (Figure 5).

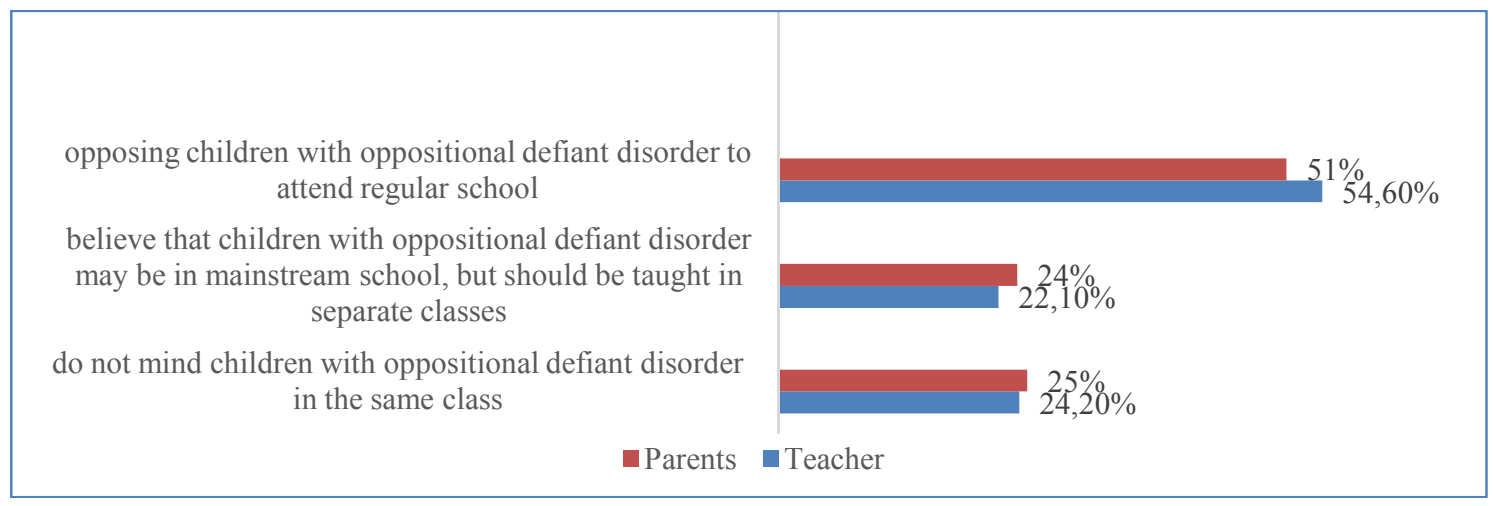

Figure 5. Attitude of teachers and parents to the possibilities of coeducation with children with developmental disabilities

Note-compiled by the authors

The results of the analysis showed that more than half of the respondents $(54.6 \%$ of teachers, $51 \%$ of parents) believe that children with disabilities should be educated in regular general education schools, and not in special educational institutions.

At the same time, a fairly large proportion of the respondents ( $46.4 \%$ of teachers, $49 \%$ of parents) do not share the ideology of inclusive education and believe that children with disabilities should study separately from their peers.

Within the framework of the educational program adopted in our country, half of the children with disabilities should be covered by inclusive education. However, experts have doubts that this figure will be achieved.

Thus, according to representatives of the Kenes center, the situation with the implementation of the idea of inclusive education is not developing in the best way. First of all, according to representatives of the center, public consciousness is not developed, including among the parents of ordinary children. Many parents and educators do not understand that being near children with special educational needs means not only educating ordinary children, but also instilling in them ethical standards, such as kindness, caring for the weak, and a sense of justice (Alayev,2016).

To build an econometric model, the author considered indicators that characterize inclusive education in the Republic of Kazakhstan for the period from 2010-2019 (Table 3) (www.stat.gov.kz).

Table 3. Indicators describing inclusive education in the Republic of Kazakhstan for the period from 2010-2019

\begin{tabular}{|c|c|c|c|c|c|c|c|c|c|c|}
\hline Indicators & 2010 & 2011 & 2012 & 2013 & 2014 & 2015 & 2016 & 2017 & 2018 & 2019 \\
\hline $\begin{array}{l}\text { Total number of children } \\
\text { with special educational } \\
\text { needs, people, of them }\end{array}$ & 149043 & 151216 & 148652 & 138513 & 141952 & 141821 & 144783 & 147396 & 153230 & 161156 \\
\hline - schoolage, person & 98657 & 99847 & 98247 & 91264 & 94115 & 94266 & 96555 & 98000 & 102329 & 106743 \\
\hline - preschoolage, person & 50386 & 51369 & 50405 & 47249 & 47837 & 47555 & 48228 & 49396 & 50901 & 54413 \\
\hline $\begin{array}{l}\text { - included in inclusive ed- } \\
\text { ucation }\end{array}$ & 27281 & 28793 & 29015 & 30984 & 31047 & 31957 & 32125 & 34920 & 35276 & 36172 \\
\hline $\begin{array}{l}\text { Number of secondary } \\
\text { schools, units }\end{array}$ & 7839 & 7790 & 7721 & 7640 & 7563 & 7511 & 7450 & 7414 & 7393 & 7398 \\
\hline $\begin{array}{l}\text { Number of teachers in sec- } \\
\text { ondary schools }\end{array}$ & 288477 & 306492 & 309755 & 312533 & 314591 & 325184 & 319167 & 334205 & 338755 & 347052 \\
\hline $\begin{array}{l}\text { Equipment of schools with } \\
\text { computers }\end{array}$ & 55782 & 578279 & 631670 & 884909 & 882677 & 935312 & 951777 & 977192 & $\begin{array}{c}104281 \\
3 \\
\end{array}$ & $\begin{array}{c}112408 \\
0 \\
\end{array}$ \\
\hline Use of Internet technologies & 45354 & 48064 & 49853 & 58456 & 52630 & 65186 & 75779 & 79658 & 100702 & 105531 \\
\hline
\end{tabular}


The author hypothesized that there is a correlation between the growth rate of the number of children enrolled in inclusive education and the rate of the number of teachers in general education schools. To prove or refute this hypothesis, a regression analysis of the statistical data presented in Table 4 was performed.

Table 4. Growth rates of the number of children enrolled in inclusive education, the number of teachers of secondary schools for 2011-2019

\begin{tabular}{|c|c|c|}
\hline Year & $\begin{array}{c}\text { The growth rate of the number of children } \\
\text { enrolled in inclusive education, } \%\end{array}$ & $\begin{array}{c}\text { The growth rate of the number } \\
\text { of secondary school teachers, } \%\end{array}$ \\
\hline 2011 & 5,542 & 6,245 \\
\hline 2012 & 0,771 & 1,065 \\
\hline 2013 & 6,786 & 0,897 \\
\hline 2014 & 0,203 & 0,658 \\
\hline 2015 & 2,931 & 3,367 \\
\hline 2016 & 0,526 & $-1,850$ \\
\hline 2017 & 8,700 & 4,712 \\
\hline 2018 & 1,019 & 1,361 \\
\hline 2019 & 2,540 & 2,449 \\
\hline \multicolumn{2}{|l}{ Note-compiled by the authors } \\
\hline
\end{tabular}

The results of the regression analysis performed using the least squares method are shown in Table 5 (Sedelev, 240).

Table 5. Results of estimating the total number of children enrolled in inclusive education

\begin{tabular}{|l|l|}
\hline$r$ & 0,843 \\
\hline $\begin{array}{l}\text { Fischer Test } \\
\text { Variables }\end{array}$ & $4,938^{*}$ \\
\hline \multicolumn{2}{|l|}{ Increase in the number of children enrolled in inclusive education $(\%)$ - dependent variable } \\
\hline Constant & 1,498 \\
\hline & Regression coefficients \\
\hline $\begin{array}{l}\text { Growth rate number of teachers of gen- } \\
\text { eral education schools (person) }\end{array}$ & $0,822^{*}$ \\
\hline$* \mathrm{p}<0,1 ; * * \mathrm{p}<0,05 ; * * * \mathrm{p}<0,01$ & \\
\hline Note - Compiled by the author
\end{tabular}

The calculations showed that the correlation coefficient for the model: $r=0.843$. This value is close to 1 , so we can talk about a strong correlation between the variables under consideration. The regression equation as a whole, as well as the regression coefficient, are statistically significant and reliable, at appropriate levels of significance.

Therefore, having a positive value in the regression equation, the effective index, we can confidently say that our hypothesis about the relationship between the growth rate of the number of children covered by inclusive education and the growth in the number of teachers in secondary schools there is a relationship. Therefore, it can be concluded that the increase in the number of teachers of general education schools contributes to an increase in the number of children covered by inclusive education.

\section{Conclusion}

Research analysis of the researched problem shows that at the present stage, inclusion is the leading trend in the development of the education system throughout the world community. The quality of development of inclusive education in Kazakhstan raises many questions from researchers, including the inefficiency of using innovative forms of education in inclusive education, insufficient knowledge of international experience, etc.

Interest in this issue is due, in our opinion, to the following reasons:

Kazakhstan is focused on the implementation of development goals, in accordance with the State Program for the Development of Education, therefore there is a need to refer to the experience of domestic science and foreign experience of public administration of inclusive education;

- lack of mass practice of inclusive education in the domestic education system;

- insufficient degree of efficiency of existing forms of organization and public administration of inclusive education in the Republic of Kazakhstan; 
- despite the significant steps of Kazakhstan in the development of inclusive education, "barrier-free schools" have not yet been created, the conditions for socialization, vocational training of children with special needs are insufficient, there is not enough teaching staff who are ready to work in an inclusive environment.

These circumstances determine the interest in the analysis of the theory, methodology, forms of organization and the system of public administration of inclusive education in Kazakhstan.

The research methods used on the basis of a trend model to identify and determine the relationship between the number of children enrolled in inclusive education and such factors as the number of teachers in secondary schools and the use of Internet technologies in the Republic of Kazakhstan Allowed us to draw conclusions for further measures for the development of inclusive education.

\section{References}

Alaev, V. (2016). Osobennosti privlecheniia na rabotu lits s ogranichennymi vozmozhnostiami v RK. Novoe pokolenie pravozashchitnikov [Features of attracting people with disabilities to work in Republic of Kazakhstan. A new generation of human rights defenders. Soros-Kazakhstan fund's project Almaty.] Proekt Fonda Soros - Kazakhstan Project of Soros - Kazakhstan fund, g.Almaty [in Russian].

Atanaev M., Amangazy M., Nogaybaeva G., Ahmetzhanova A., Shakenova M.,Karbayeva Zh., Zhumabayeva Zh., Kassymbekova N., Dauliev M., Abdrasheva D., Kussydenova A. Natsionalnyi doklad o sostoianii i razvitii sistemy obrazovaniia Respubliki Kazakhstan (po itogam 2018 goda). 2019. [National report on the state and development of the system of the Republic of Kazakhstan (based on the results of 2018)]. Ministerstvo obrazovaniia $i$ nauki Respubliki Kazakhstan - AO «Informatsionno-analiticheskii tsentr-Mnistry of education and science of RK-Joint-Stock Companyof analytical department of ministry of education and science of RK, 364 [in Russian].

Biktagirova, G. F. \&Khitryuk, V.V. (2016). Formation of Future Pre-School Teachers Readiness to Work in the Conditions of Educational Inclusion. International Journal of Environmental \&Science Education, 185-194. DOI: 10.12973/ijese.2016.302a [in Russian].

Dannye Komiteta po statistike Respubliki Kazakhstan za 2010-2019 gg. [Data of the Committee on Statistics of the Republic of Kazakhstan for 2010-2020]. http://stat.gov.kz [in Russian].

Dyssegaard, C.B.\& Larsen M.S. (2013). Evidence of inclusion. Copenhagen, Danish clearing house for educational research, 55.

Giangrego, M. \& Doyle, M.B. (2012). Integrazion scolastica in Italy [International journal of whole schooling]. Compilation of English-Language Resources, 63-105.

Gosudarstvennaia programma razvitiia obrazovaniia v Respublike Kazakhstan na 2011-2020 gody, utverzhdennaia Ukazom Prezidenta RK № 1118 ot 7 dekabria. 2010 g. [State program of education development in the Republic of Kazakhstan for 2011-2022 approved by the decree of the President № 1118 from 7 of December] [in Russian].

Hosford, S. \& O'Sullivan, S.A. (2016). Climate for Self-Efficacy: The Relationship Between School Climate and Teacher Efficacy for Inclusion. International Journal of Inclusive Education, 604-621. DOI: 10.1080/13603116.2015.1102339.

Natsionalnaia akademiia obrazovaniia I. Altynsarina. (2015). Kontseptualnye podkhody k razvitiiu inkliuzivnogo obrazovaniia v Respublike Kazakhstan [Conceptual approaches to inclusive education development. National educational academy of Altynsaryn I]. Astana, 16 [in Russian].

Nogaibaeva, G., Zhumazhanova, S. \&Korotkikh, E. (2017). Ramka monitoringa inkliuzivnogo obrazovaniia v Respublike Kazakhstan [Inclusive education monitoring framework in RK]. Astana: IATs, 187 [in Russian].

Safonova, T.V., Suntsova, A.S. \& Aslaeva, R.G. (2019). Issledovanie orientatsii na lichnostnuiu model vzaimodeistviia $\mathrm{s}$ detmi kak strukturnogo komponenta gotovnosti pedagogov k inkliuzivnomu obrazovaniiu [Research of orientations on the personal model of interaction with children as a structural component of teachers ' readiness for inclusive education]. Integratsiia obrazovaniia — Integration of education, 50-65. DOI: 10.15507/19919468.094.023.201901.050-065 [in Russian].

Sagner-Tapia, J. (2017). An Analysis of Alterityin Teachers' Inclusive Pedagogical Practices. International Journal of Inclusive Education, 375-390. DOI: 10.1080/13603116.2017.1370735.

Sait zhurnala «Kapital tsentr delovoi informatsii» [Site of journal "Capital is the centre of business information]. kapital.kz. Retrieved from http://kapital.kz [in Russian].

Sedelev, B.V. (2009). Regressionnye modeli i metody otsenki parametrov i struktury ekonomicheskikh protsessov [Regression models and methods for estimating parameters in the structure of economic processes. The textbook under the editorship of V.V. Kharitonova]. V.V. Kharitonov (Ed.). Study guide edited, by V.V. Kharitonov, 240 [in Russian].

Sshlessinger, S. (2018). Reclaiming Teacher Intellectualism Through and for Inclusive Education. International Journal of Inclusive Education, 268-284. DOI: 10.1080/13603116.2017.1362598.

Suleimenova, R.A. (2015). K voprosu ob inkliuzivnom obrazovanii [The question of inclusive education, «Open school» august]. Otkrytaia shkola — The open school, № 06 (147), S. 56-58 [in Russian]. 
Svenja, B. (2016). Personality Traits of Expert Teachers of Students with Ebd. Clarifying a Teacher's X-Factor International Journal of Inclusive Education, 569-587. DOI: 10.1080/13603116.2015.1100222

Timo, S. (2018). How Common are Inclusive Educational Practices Among Finnish Teachers? International Journal of Inclusive Education, 560-575. DOI: 10.1080/13603116.2017.1390001.

Zakon RK «Ob obrazovanii» ot 27 iiulia 2007 goda № 319-III (s izmeneniiami i dopolneniiami po sostoianiiu na 07.07.2020 g.) [The Law on education of July 27 № 319- with amendments and additions as of 07.07.2020] [in Russian].

\section{М.Б. Турлубекова, Р.О. Бугубаева, Р.С. Беспаева \\ Қазақстан Республикасындағы инклюзивті білім беру және оның дамуына әсер етуші факторлар}

\section{Аңдатnа:}

Maқ̧саты: Мемлекеттік саяси басқару контексіндегі инклюзивті білім беру жүйесі болып табылады.

Әдістері: Зерттеу аясында мына әдістер қолданылды: теориялық, эмпирикалық әдістер, деректерді сапалы өңдеу әдістері, математикалық және статистикалық өңдеу әдістері: рейтинг, корреляция. Эконометрикалық модель құрылды, ол инклюзивті білім берумен қамтылған балалар санының өсу қарқыны мен жалпы білім беретін мектептердегі мұғалімдер санының өсу қарқыны арасындағы өзара байланыстың болуы туралы гипотезаны тексеруге мүмкіндік берді. Зерттеу нәтижелері мен қорытындылары алынған нәтижелерді ұсынудың графикалық әдісі арқылы ұсынылды. Экономикалық құбылыстарды зерттеудің және бастапқы ақпаратты өңдеудің пайдаланылған әдістері талдаудың сенімділігі мен қорытындылардың дұрыстығын қамтамасыз етеді.

Нәтижелері: Авторлар инклюзивті біліммен қамтылған балалар санының өсу қарқыны мен жалпы білім беретін мектептердегі мұғалімдер санының өсу қарқыны арасында байланыстың болуы туралы гипотеза ұсынды. Бұл гипотезаны дәлелдеу немесе теріске шығару үшін авторлар регрессиялық талдау жүргізді, нәтижесінде жалпы білім беретін мектептердегі педагогтер санының көбеюі маңызды міндеттердің бірі болып табылатын инклюзивті білім беруді одан әрі дамыту үшін маңызды және қажетті шарт болып табылады деген қорытынды жасалды.

Kорылтынды: Жүргізілген регрессиялық талдау негізінде мақала авторлары жалпы білім беретін мектеп педагогтері санының артуы инклюзивті білім берумен қамтылған балалар санының артуына ықпал етеді деген қорытынды жасады. Зерттеліп отырған проблема бойынша зерттеу талдауы қазіргі кезеңде инклюзивті білім беру жүйесін дамытудағы жетекші үрдіс болып табылатынын көрсетеді. Қазақстанда инклюзивті білім беруді дамыту сапасы зерттеушілерде көптеген сұрақтар туғызады, соның ішінде инклюзивті білім беруде оқытудың инновациялық түрлерін қолданудың тиімсіздігі, халықаралық тәжірибені жеткіліксіз зерттеу және т. б. Сондықтан аталған мән-жайлар Қазақстандағы инклюзивті білім беруді мемлекеттік басқару теориясы, әдіснамасы, ұйымдастыру нысандары мен жүйесін талдауға және оны одан әрі пысықтауға қызығушылық тудырады.

Кілт сөздер: инклюзивті білім беру, білім беру жүйесі, қосу, басқару, мектеп алды білім беру, реттеу, басқару жүйесі, инновациялық білім беру.

\section{М.Б. Турлубекова, Р.О. Бугубаева, Р.С. Беспаева}

\section{Инклюзивное образование в Республике Казахстан и факторы его развития}

\section{Аннотация}

Цель: Цель исследования — изучить систему инклюзивного образования в контексте государственной политики управления.

Meтодb: В рамках проведенного исследования применялись следующие методы: теоретические, анализ законодательных и нормативных документов по внедрению инклюзивного образования и образования в целом, эмпирические методы, методы качественной обработки данных, методы математической и статистической обработки: ранжирование, корреляция. Была построена эконометрическая модель, которая позволила проверить гипотезу о наличии взаимосвязи между темпами прироста количества детей, охваченных инклюзивным образованием, и темпами прироста численности педагогов общеобразовательных школ. Выводы и результаты исследования были представлены с помощью графического метода предоставления полученных результатов. Использованные методы исследования экономических явлений и обработки первичной информации в своей совокупности позволяют обеспечить достоверность анализа и обоснованность выводов.

Результаты исследования: Авторами была выдвинута гипотеза о наличии связи между темпами прироста количества детей, охваченных инклюзивным образованием, и темпами прироста численности педагогов общеобразовательных школ. Для доказательства либо опровержения этой гипотезы проведен регрессионный анализ.

Bblвoдbl: На основе проведенного регрессионного анализа авторами статьи был сделан вывод, что увеличение числа педагогов общеобразовательных школ способствует увеличению количества детей, охваченных инклюзивным образованием. Исследовательский анализ по проблеме показывает, что на современном этапе 
инклюзия является ведущей тенденцией в развитии системы образования. Качество развития инклюзивного образования в Казахстане вызывает множество вопросов у исследователей, в том числе и неэффективность применения инновационных форм обучения в инклюзивном образовании, а также недостаточная изученность международного опыта и т.д.

Ключевые слова: инклюзивное образование, система образования, инклюзия, управление, дошкольное образование, регулирование, система управления, инновационное образование.

\section{References}

Biktagirova G. F., Khitryuk V. V. Formation of Future Pre-School Teachers Readiness to Work in the Conditions of Educational Inclusion // International Journal of Environmental \& Science Education. — 2016. — № 11(3). — P. 185-194. DOI: 10.12973/ijese.2016.302a

Dyssegaard, C.B., Larsen M.S. Evidence of inclusion [Text] / C.B. Dyssegaard, M.S. Larsen. — Copenhagen: Danishc learing house for educational research. - 2013. - P. 55.

Giangrego, M., Doyle, M. B. Integrazions colasticain Italy: A Compilation of English-Language Resources [Text] // International journal of whole schooling. 2012. - 8 (1). - P. 63-105.

Hosford S., O’Sullivan S. A Climate for Self-Efficacy: The Relationship Between School Climate and Teacher Efficacy for Inclusion // International Journal of Inclusive Education. — 2016. — № 20(6). — P. 604-621. DOI: 10.1080/13603116.2015.1102339

Personality Traits of Expert Teachers of Students with Ebd: Clarifying a Teacher's X-Factor / B. Svenja [etal.] //International Journal of Inclusive Education. - 2016. — № 20(6). — P. 569-587. DOI:10.1080/13603116.2015.1100222

Sagner-Tapia J. An Analysis of Alterityin Teachers' Inclusive Pedagogical Practices // International Journal of Inclusive Education. - 2017. — № 22(4). — P. 375-390. DOI: 10.1080/13603116.2017.1370735

Schlessinger S. Reclaiming Teacher Intellectualism Through hand for Inclusive Education // International Journal of Inclusive Education. — 2018. — № 22(3). P. 268-284. DOI: 10.1080/13603116.2017.1362598

Timo S. How Commonare Inclusive Educational Practices Among Finnish Teachers? // International Journal of Inclusive Education. - 2018. — № 22 (5). — P. 560-575. DOI: 10.1080/13603116.2017.1390001

Алаев В. Особенности привлечения на работу лиц с ограниченными возможностями в РК / В. Алаев // Новое поколение правозащитников. Проект Фонда Сорос-Казахстан. - Алматы, 2016.

Атанаева М. Национальный доклад о состоянии и развитии системы образования Республики Казахстан (по итогам 2018 года) / М. Атанаева, М. Аманғазы, Г. Ногайбаева, А. Ахметжанова, М. Шакенова, Г. Карбаева, Ж. Джумабаева, Н. Касымбекова, М.Даулиев, Д. Абдрашева, А. Кусиденова. - Нур-Султан: Министерство образования и науки Республики Казахстан: АО «Информационно-аналитический центр», 2019. С. 364.

Государственная программа развития образования в Республике Казахстан на 2011-2020 годы. Утв. Указом Президента РК. — № 1118 от 7 дек. 2010 г.

Закон РК «Об образовании» от 27 июля 2007 года № 319-ІІІ (с изм. и доп. по состоянию на 07.07.2020 г.)

Концептуальные подходы к развитию инклюзивного образования в Республике Казахстан. - Астана: Национальная академия образования им. И. Алтынсарина, 2015. - С. 16.

Ногайбаева Г. Рамка мониторинга инклюзивного образования в Республике Казахстан / Г. Ногайбаева, С. Жумажанова, Е. Коротких. - Астана: ИАЦ, 2017 - 187 с.

Сафонова Т.В. Исследование ориентации на личностную модель взаимодействия с детьми как структурного компонента готовности педагогов к инклюзивному образованию / Т.В. Сафонова, А.С. Сунцова, Р.Г. Аслаева // Интеграция образования. — 2019. — Т. 23. — № 1. — C. 50-65. DOI: 10.15507/19919468.094.023.201901.050-065

Седелев Б.В. Регрессионные модели и методы оценки параметров и структуры экономических процессов: учеб. пос. / Б.В. Седелев; под ред. В.В. Харитонова. - М., 2009. - С. 240.

Сулейменова Р. А. К вопросу об инклюзивном образовании. «Открытая школа». — № 6 (147). — Август, 2015. - С. 56-58.

Электронный pecypc: https://kapital.kz/business/26184/obshchestvennoye-soznaniye-meshayet-realizatsiiinklyuzivnogo-obrazovaniya-v-rk.html

Электронный ресурс: Данные Комитета по статистике Республики Казахстан за 2010-2019 гг. //www.stat.gov.kz 